\title{
Anti browning and antioxidant properties of Foeniculum vulgare seed extracts
}

\author{
Joo-Yeon Lee, Choon Young Kim* \\ Department of Food and Nutrition, Yeungnam University, Gyeongsan 38541, Korea
}

\section{회향씨앗 추출물의 항갈변 및 항산화 효과}

\author{
이주연 · 김춘영* \\ 영남대학교 식품영양학과
}

\begin{abstract}
Since the occurrence of enzymatic browning during manufacture reduces the quality of the fresh-cut food products, the utilization of anti browning agents is essential. The development of a natural food additive that inhibits browning while also exhibiting health benefits is important to meet consumer demand for fresh and healthy products. Although Fennel (Foeniculum vulgare Miller) seed has various health beneficial effects, its application as an anti browning agent in foods has yet to be examined. The purpose of this study was therefore to investigate the potential of fennel seed as an anti browning additive with antioxidant activity. Fennel seed ethanol extract (FSEE) inhibited the activity of potato polyphenol oxidase (PPO) by $85.47 \%$ at a concentration of $10 \mathrm{mg} / \mathrm{mL}$ and presented an $\mathrm{IC}_{50}$ value of $1.50 \pm 0.17 \mathrm{mg} / \mathrm{mL}$. FSEE appeared to be a noncompetitive inhibitor against potato PPO, as indicated by Lineweaver-Burk plot. In addition, the color difference $(\Delta E)$ values of potato extracts treated with the 0 and $10 \mathrm{mg} / \mathrm{mL}$ FSEE were $13.82 \pm 1.10$ and $1.46 \pm 0.2$, respectively, thereby confirming the anti browning activity of FSEE. Furthermore, FSEE exhibited a dose-dependent antioxidant activity as demonstrated by radical scavenging activity and ferric reducing ability power assays. The total polyphenol and total flavonoid contents at $2 \mathrm{mg} / \mathrm{mL}$ of FSEE were $1.52 \mathrm{mgGAE} / \mathrm{mL}$ and $2.05 \mathrm{mgCE} / \mathrm{mL}$, respectively. FSEE could therefore be considered a natural additive to inhibit enzymatic browning while improving the nutritional value of the fresh-cut food products.
\end{abstract}

Key words : Foeniculum vulgare, enzymatic browning, antioxidant activity, polyphenol oxidase, potato

\begin{abstract}
서 론
최근 소비자들의 식품구매 형태가 천연물 선호 및 건강 지향적으로 변화함과 동시에 1 인 및 핵가족 가구의 증가로 신선함과 편리성을 갖춘 최소 가공처리된 신선편이제품 의 수요가 증가하고 있다(Ragaert 등, 2004). 신선편이제품 은 농산물 특유의 신선함을 유지하면서 세척, 박피, 절단 등의 제조공정을 거쳐 소비자의 구매 요구에 맞춰 단위 포장하여 유통되는 제품류이다(Lim 등, 2005). 그러나 신
\end{abstract}

선편이제품은 필연적으로 제조공정 중의 조직손상으로 인한 갈변(browning), 미생물 번식, 연화, 악취 등의 문제가 발생하여 제품의 품질 저하를 야기한다(Braaksma 등, 1999). 특히, 농산물 신선편이제품의 표면갈변은 소비자들이 식 품 구매 시 눈으로 바로 확인할 수 있는 품질 지표로 상품성 을 좌우하는 중요한 요인이 된다(Martinez과 Whitaker, 1995; Kim과 Uyama, 2005).

감자는 신선편이제품 제조공정에서 박피와 절단으로 인한 표면의 공기 노출과 세포벽 파괴로 효소적 갈변

${ }^{*}$ Corresponding author. E-mail : cykim@yu.ac.kr, Phone :+82-53-810-2871, Fax :+82-53-810-4666

Received 12 April 2019; Revised 04 June 2019; Accepted 13 June 2019.

Copyright (c) The Korean Society of Food Preservation.

This is an Open Access article distributed under the terms of the Creative Commons Attribution Non-Commercial License (http://creativecommons.org/licenses/by-nc/4.0) which permits unrestricted non-commercial use, distribution, and reproduction in any medium, provided the original work is properly cited. 
(enzymatic browning)이 쉽게 발생하며, 이로 인해 유통기 한이 짧아지고 상품성이 떨어지는 대표적인 농산물이다. 이러한 효소적 갈변의 주원인은 polyphenol oxidase(PPO) 이며, $\mathrm{PPO}$ 는 $\mathrm{Cu}^{2+}$ 를 함유하고 있는 효소로서 세포 내에 존재하는 polyphenol 화합물을 산화시켜 L-3,4-dihydroxyphenylalanine(L-DOPA)으로 전환되고, L-DOPA는 DOPAquinone으로 전환된다. 이후 산화적 중합 반응을 거쳐 흑갈 색의 melanin 색소를 형성하는 갈변 현상을 일으킨다(Chen 등, 1991; Martinez과 Whitaker, 1995; Kim과 Uyama, 2005).

식품산업에서 효소적 갈변을 막기 위하여 황화합물, ascorbic acid, citric acid, ethylenediaminetetraacetic acid (EDTA) 등의 합성화합물을 사용해 왔다(Laurila 등, 1998). 그러나 식품 선택 시 소비자의 건강에 대한 관심은 화학물 질을 대체할 수 있는 천연물질에 대한 구매 욕구로 이어지 고 있다. 따라서 효소적 갈변을 억제하는 천연물에 대한 연구가 활발히 진행되어져 왔다. 예를 들어, 천연물인 꿀 (Oszmianski과 Lee, 1990), 양파 추출물(Kim 등, 2005), 루바 브 추출물(Son 등, 2000), 녹차 추출물(Chang 등, 2012) 등이 식품의 $\mathrm{PPO}$ 를 억제하는 효과를 보여 천연 갈변저해제로 보고된 바 있다. $\mathrm{PPO}$ 의 초기속도를 기질 epicatechin의 농 도별로 측정하였을 때 $\mathrm{PPO}$ 는 Michaelis-Menten 방정식을 따르는 효소이며, 천연 추출물 중 꿀은 식품 속 $\mathrm{PPO}$ 와 비경쟁적으로 작용한다(Oszmianski과 Lee, 1990). 양파 추 출물은 thiol compounds를 함유하여 배 $\mathrm{PPO}$ 와 비경쟁적으 로 작용하며, 양파 추출물을 가열 시에 갈변 저해 효과가 더 우수하다고 보고되었다(Kim 등, 2005). 루바브는 oxalic $\mathrm{acid}$ 가 들어있어 항갈변 효과를 보이며 무색, 무취로 가공 시에도 효과가 있음을 보였다(Son 등, 2000).

또한, polyphenol이 풍부한 천연물의 경우 항갈변 효과 와 더불어 항산화 효능을 확인한 여러 연구결과가 보고된 바 있다. Lee 등(2004)은 이팝나무 잎의 용매분획물에서 높은 항산화 활성과 tyrosinase 저해 효과를 확인하여 식품 첨가물로서의 이용가치가 있다고 보고하였고, $\mathrm{Kim}$ 등 (2016)은 사과주스에 양파를 첨가하면 항갈변 효과와 항산 화 효과가 증가되는 것을 확인 후 양파추출물의 첨가가 사과주스의 품질을 향상시킨다고 결론지었다. 이들의 연 구결과를 토대로 기능성 화합물이 풍부한 천연추출물을 항갈변제로 사용할 경우 영양학적 가치가 높아져 상품성 이 우수해진다고 할 수 있다.

회향(Foeniculum vulgare)은 미나리과에 속하는 식물로 고대부터 지중해 주변 국가에서 재배되어 왔으나, 현재는 한국을 포함한 많은 국가에서 재배하고 있다. 그 중 회향씨 앗은 회향열매를 말린 것을 뜻하며, 항균제, 진통제, 이뇨 제, 항경련제 등으로서 민간에서 의학적으로 사용되었다. 또한, 방향족 식물로서 특유의 풍미로 인해 향신료, 샐러드 소스, 주류, 제과 등에 식재료로도 사용되어 왔다(Oktay
등, 2003; Anwar 등, 2009). 회향의 기능성 성분으로는 trans-anethole, estragole, fenchone 및 limonene 등이 보고되 었다. Trans-anethole은 페놀성분으로 회향 에센셜 오일의 주성분이며 에스트로겐 활성, 혈관이완, 항혈전 기능을 하며, estragole은 페놀 배당체로 소독 살균작용을 하며, fenchone은 방향족 화합물로 항균, 항진균 작용을 하는 것으로 알려져 있다(Cho 등, 2008; Rather 등, 2016). 그러나 풍부한 천연자원으로서 회향씨앗 추출물과 회향에션셜 오일의 항산화, 항균 및 다양한 약리작용을 살펴본 연구 (Oktay 등, 2003; Anwar 등, 2009; Rather 등, 2016)는 있으 나, 식품에 적용하여 항갈변 효과를 살펴본 연구는 아직 보고된 바 없다.

따라서 본 연구에서는 최근 신선편이 제품에서 다소비 되고 있는 감자의 가공과정에서 품질저하의 주요 원인이 되는 효소적 갈변을 막으면서 식품의 기능성을 높일 수 있는 천연물을 찾고자 한다. 천연 기능성 갈변저해제로서 회향씨앗의 기능을 밝히기 위하여 회향씨앗 추출물의 감 자 PPO 저해효과와 항산화 효과를 조사하였다.

\section{재료 및 방법}

\section{실험재료}

본 실험에 사용된 시약은 Sigma-Aldrich Co.(St. Louis, $\mathrm{MO}, \mathrm{USA}$ )에서 구입하여 사용하였다. 실험재료인 회향씨 앗은 2017년 주식회사 토종마을(tojongherb.com)에서 구입 하였고, 감자는 경북 경산의 일반마트에서 구입하여 외관 에 흠집이 없는 것으로 선별하여 실험에 사용하였다.

\section{회향 추출물 제조}

회향씨앗 에탄올추출물(Fennel Seed Ethanol Extract, $\mathrm{FSEE}$ 은 회향씨앗 $50 \mathrm{~g}$ 에 $500 \mathrm{~mL}$ 의 $80 \%$ ethanol을 가해 $40^{\circ} \mathrm{C}$ 에서 24 시간 동안 추출한 후 여과하여 준비하였다. FSEE는 rotary vacuum evaporator(N-1300, EYELA, Tokyo Rikakikai Co., Ltd., Tokyo, Japan)를 사용하여 $40^{\circ} \mathrm{C}$ 수욕 상에서 감압농축하였다. 추출물은 동결건조기(FD8508, ilShinBioBase Co., Ltd., Dongducheon, Korea)를 사용하여 $5 \mathrm{mTorr}$ 의 감압조건하에서 동결건조하였다(수율, $3.57 \%$ ). 동결건조된 $\mathrm{FSEE}$ 분말은 $-20^{\circ} \mathrm{C}$ 에 보관하며 사용하였으 며, dimethyl sulfoxide(DMSO)에 용해하여 100 배 농도의 stock 용액을 만들어 사용 직전에 증류수에 필요한 농도로 희석하여 사용하였다.

\section{감자 crude polyphenol oxidase(PPO) 조제}

감자와 동량의 $50 \mathrm{mM}$ phosphate buffer( $\mathrm{pH}$ 7.0)를 혼합한 후 stomacher(BagMixer, Interscience, St. Nom, France)를 이용 하여 감자를 균질화한 후 여과하였다. 여과액을 원심분리기 
(Supra R22, Hanil, Gimpo, Korea)를 이용하여 $4^{\circ} \mathrm{C}$ 온도 조건 하에서 $11,000 \times g$ 에서 20 분 동안 원심분리하여 얻은 상등 액을 감자 crude polyphenol oxidase(PPO)로 사용하였다.

\section{$\mathrm{FSEE}$ 의 감자 $\mathrm{PPO}$ 에 대한 활성 억제능 측정}

$\mathrm{FSEE}$ 의 감자 $\mathrm{PPO}$ 활성 억제능 측정은 $50 \mathrm{mM}$ phosphate buffer(pH 6.8) $60 \mu \mathrm{L}$ 와 FSEE $100 \mu \mathrm{L}$ 를 혼합 후 감자 $\mathrm{PPO}$ $20 \mu \mathrm{L}$ 를 첨가하여 $37^{\circ} \mathrm{C}$ 에서 30 분간 반응시킨 후 기질 25 $\mathrm{mM}$ catechol을 $40 \mu \mathrm{L}$ 가하여 microplate spectrophotometer (Epoch, Bio-Tek, Winooski, Vermont, USA)로 $420 \mathrm{~nm}$ 에서 5 분 동안 1 분 단위로 시료 농도별 흡광도 값의 변화율을 측정하였다.

또한, Chroma meter(CR-300, Minolta Co., Osaka, Japan) 를 사용하여 색도측정을 하였다. Hunters' color value는 표준백색판 $(\mathrm{L}=93.70, \mathrm{a}=0.31, \mathrm{~b}=0.32)$ 으로 보정 후 $\mathrm{L}$ 값 (lightness), a값(redness), $\mathrm{b}$ 값(yellowness)을 측정하였다. 각 $\mathrm{FSEE}$ 의 갈변도는 색차(color difference, $\triangle \mathrm{E}$ )를 이용하여 분석하였으며 계산식은 다음과 같다.

$$
\Delta E=\sqrt{\left(L-L^{\prime}\right)^{2}+\left(a-a^{\prime}\right)^{2}+\left(b-b^{\prime}\right)^{2}}
$$

여기서 $\mathrm{L}, \mathrm{a}, \mathrm{b}$ 는 효소 반응 전 측정치이며, $\mathrm{L}^{\prime}, \mathrm{a}^{\prime}, \mathrm{b}^{\prime}$ 은 $37^{\circ} \mathrm{C}$ 에서 30 분간 효소 반응 후의 측정치이다.

\section{$\mathrm{FSEE}$ 의 감자 $\mathrm{PPO}$ 에 대한 저해모드 평가}

FSEE $100 \mu \mathrm{L}$ 에 $50 \mathrm{mM}$ phosphate buffer(pH 6.8) $60 \mu \mathrm{L}$ 와 감자 PPO $20 \mu \mathrm{L}$ 를 혼합하여 $37^{\circ} \mathrm{C}$ 에서 30 분간 반응하였다. 이후 $3.3 \mathrm{mM}, 16.6 \mathrm{mM}, 50 \mathrm{mM}$ 농도로 준비한 catechol을 각각 $40 \mu \mathrm{L}$ 씩 첨가하여 $420 \mathrm{~nm}$ 에서 흡광도를 측정하였다. $\mathrm{FSEE}$ 에 대한 감자 $\mathrm{PPO}$ 활성 저해모드는 기질농도(S)의 역수와 효소반응속도(V)의 역수를 활용하여 LineweaverBurk plot을 그린 후 $K_{m}, V_{\max }$ 값을 구하여 판단하였다.

\section{DPPH radical 소거능 측정}

FSEE의 DPPH radical 소거능 측정은 Brand-Williams의 방법을 변형하여 실시하였다(Brand-Williams 등, 1995). 각 농도별 $(0 \mathrm{mg} / \mathrm{mL}, 2.5 \mathrm{mg} / \mathrm{mL}, 5 \mathrm{mg} / \mathrm{mL}, 10 \mathrm{mg} / \mathrm{mL})$ FSEE $50 \mu \mathrm{L}$ 와 $0.02 \%$ 1,1-diphenyl-2-picrylhydrazyl(DPPH) 100 $\mu \mathrm{L}$ 를 혼합하여 암실에서 30 분간 반응시킨 후, $510 \mathrm{~nm}$ 에서 microplate spectrophotometer를 이용하여 흡광도를 측정하 였다. 표준물질로는 기존의 알려진 항산화제인 ascorbic acid를 다양한 농도로 녹여 동일한 방식으로 흡광도를 측 정 후 표준곡선을 작성하였다. 이때 FSEE 추출물에 함유 된 $\mathrm{DPPH}$ radical 소거능은 표준곡선으로부터 구하였으며, 측정단위는 milligram ascorbic acid equivalent(mgAAE) $/ \mathrm{mL}$ 를 사용하였다.

\section{ABTS radical 소거능 측정}

FESS의 2,2'-azino-bis(3-ethylbenzothiazoline-6-sulphonic acid)(ABTS) radical 소거능 측정은 Biglari의 방법으로 분 석하였다(Biglari 등, 2008). ABTS solution은 $7.4 \mathrm{mM} \mathrm{ABTS}$ 와 $2.6 \mathrm{mM}$ potassium persulfate 용액을 1:1로 혼합한 후 암실에서 16 시간 동안 반응시켜 $734 \mathrm{~nm}$ 에서 흡광도 값이 $0.70 \pm 0.02$ 가 되게 증류수로 희석하여 제조하였다. 각 농도 별 FSEE $10 \mu \mathrm{L}$ 와 $\mathrm{ABTS}$ solution $190 \mu \mathrm{L}$ 를 6분간 상온에서 반응시킨 후 $732 \mathrm{~nm}$ 에서 흡광도를 측정하였다. 표준물질 로는 trolox를 다양한 농도로 녹여 동일한 방식으로 흡광도 를 측정한 후 표준곡선을 작성하였고 이를 통하여 FSEE의 ABTS radical 소거능을 구하였다. 측정 단위는 micromole trolox equivalent $(\mu \mathrm{MTE}) / \mathrm{mL}$ 를 사용하였다.

\section{FRAP assay}

$\mathrm{FSEE}$ 의 $\mathrm{Fe}^{3+}$ 이온을 $\mathrm{Fe}^{2+}$ 이온으로 환원시키는 환원력을 측정하는 ferric reducing antioxidant power(FRAP) assay는 Benzie의 방법으로 실시하였다(Benzie과 Strain, 1996). FRAP reagent는 $300 \mathrm{mM}$ sodium acetate buffer(pH 3.6), $40 \mathrm{mM}$ $\mathrm{HCl}$ 에 녹인 $10 \mathrm{mM} \mathrm{2,4,6-tripyridyl-s-triazine(TPTZ),} \mathrm{그리}$ 고 $20 \mathrm{mM}$ ferric chloride를 $10: 1: 1(\mathrm{v} / \mathrm{v} / \mathrm{v})$ 의 비율로 혼합하여 $37^{\circ} \mathrm{C}$ 에서 20 분간 반응시켜 준비하였다. 각 농도별 $\mathrm{FSEE}$ $10 \mu \mathrm{L}$ 에 $10 \mu \mathrm{L}$ 의 증류수와 $100 \mu \mathrm{L}$ 의 FRAP reagent를 첨가 하여 $593 \mathrm{~nm}$ 에서 흡광도를 측정하였다. 표준물질로는 다 양한 농도의 ferrous sulfate를 동일한 방식으로 흡광도를 측정 후 표준곡선을 작성하였다. 이를 통해 FSEE에 함유 된 환원력을 구하였으며, 측정 단위는 micromole ferrous $\left(\mu \mathrm{MFe}^{2+}\right) / \mathrm{mL}$ 를 사용하였다.

\section{FSEE의 총 폴리페놀 함량 측정}

총 폴리페놀 함량을 측정하기 위해서 Folin-Ciocalteau법 을 이용하여 실험하였다(Singleton 등, 1999). DMSO로 녹 인 stock을 증류수로 희석한 각 농도별 $(0 \mathrm{mg} / \mathrm{mL}, 0.25$ $\mathrm{mg} / \mathrm{mL}, 0.5 \mathrm{mg} / \mathrm{mL}, 1 \mathrm{mg} / \mathrm{mL}, 2 \mathrm{mg} / \mathrm{mL}$ ) FSEE $10 \mu \mathrm{L}$ 와 $20 \mu \mathrm{L}$ 의 $10 \%$ Folin-Ciocalteau reagent를 혼합하고 여기에 $80 \mu \mathrm{L}$ 의 $700 \mathrm{mM}$ sodium carbonate를 첨가하여 1 시간 동안 상온에서 반응시킨 후 $765 \mathrm{~nm}$ 에서 흡광도를 측정하였다. 표준물질로는 gallic acid를 95\% methanol에 다양한 농도로 녹여 동일한 방법으로 흡광도를 측정 후 표준곡선을 작성 하였고 이를 이용하여 $\mathrm{FSEE}$ 의 총 폴리페놀 함량을 계산하였 다. 측정 단위는 milligram gallic acid equivalent $(\mathrm{mgGAE}) / \mathrm{mL}$ 를 사용하였다.

\section{FSEE의 총 플라보노이드 함량 측정}

FSEE의 총 플라보노이드 함량은 aluminum chloride colorimetric 방법으로 측정하였다(Biglari 등, 2008). 각 농 
도별 FSEE $25 \mu \mathrm{L}$ 에 $125 \mu \mathrm{L}$ 의 증류수와 $10 \mu \mathrm{L}$ 의 $5 \%$ sodium nitrite solution을 혼합하여 6 분간 방치 후, $15 \mu \mathrm{L}$ 의 $10 \%$ aluminum chloride hexahydrate를 첨가하여 5 분간 상온에서 반응시켰다. 여기에 $50 \mu \mathrm{L}$ 의 $1 \mathrm{M}$ sodium hydroxide와 125 $\mu \mathrm{L}$ 의 증류수를 첨가한 후 $510 \mathrm{~nm}$ 에서 흡광도를 측정하였 다. 총 플라보노이드 함량은 catechin의 표준곡선으로부터 구하였으며, 측정단위는 milligram catechin $(\mathrm{mgCE}) / \mathrm{mL}$ 를 사용하였다.

\section{통계처리}

모든 실험은 최소 3회 반복 실시하였고, 결과치를 평균 표준편차로 표시하였다. 실험결과는 SPSS 통계프로그램 (version 23.0, SPSS Inc, Chicago, IL, USA)을 이용하여 분석 하였다. One-way ANOVA로 각 실험군 간 평균의 차이가 유의미한지 $(\mathrm{p}<0.05)$ 를 검증한 후, 기준 그룹에 대하여 Dunnett's pairwise 2-tailed t-test와 Duncan's multiple range test로 평균값 간에 $\mathrm{p}<0.05$ 수준에서 유의성을 검정하였다.

\section{결과 및 고찰}

Fennel seed ethanol extracts(FSEE)의 감자 polyphenol oxidase(PPO) 효소 활성 저해 평가

Polyphenol oxidase(PPO)는 구리이온 $\left(\mathrm{Cu}^{2+}\right)$ 을 함유한 산 화효소로서 채소와 과일에서 일반적으로 발견된다(Chen 등, 1991). 항갈변제들은 polyphenol성 화합물의 산화를 저 해시켜 이루어지는 반응으로, 본 연구에서는 FSEE의 항갈 변 효과를 알아보기 위하여 catechol을 기질로 사용하여 감자 $\mathrm{PPO}$ 효소 저해능을 측정하였다. $\mathrm{FSEE}$ 의 감자 $\mathrm{PPO}$ 활성 저해능을 조사한 결과는 농도의존적 저해능을 보였 다(Fig. 1). FSEE의 농도가 높을수록 $\mathrm{PPO}$ 저해능은 유의적 으로 높아져 FSEE 농도 $2.5 \mathrm{mg} / \mathrm{mL}$ 에서 $40.82 \%$, 농도 5 $\mathrm{mg} / \mathrm{mL}$ 에서 $57.27 \%$, 가장 높은 농도인 $10 \mathrm{mg} / \mathrm{mL}$ 의 FSEE

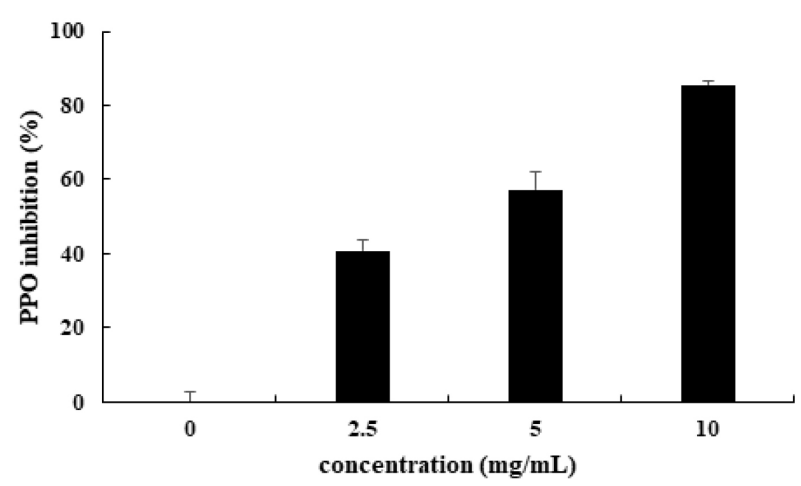

Fig. 1. Inhibitory effect of fennel seed ethanol extract (FSEE) on potato polyphenol oxidase (PPO) activity.

PPO activity was spectrophotometrically evaluated using catechol as a substrate at $420 \mathrm{~nm}$ in the absence or the presence of FSEE. The data shown are the means \pm SD of at least three independent experiments $(n=6)$. Statistical analysis was performed using Dunnett's test $\left({ }^{* * *} \mathrm{p}<0.001\right.$ vs control).

에서는 $85.47 \%$ 의 저해능을 보였다.

색차계를 이용하여 측정한 $\mathrm{FSEE}$ 의 감자 $\mathrm{PPO}$ 저해능 결과는 Table 1과 같다. 효소반응이 일어나기 전에 측정 된 $\mathrm{L}$ 값, $\mathrm{b}$ 값은 시료농도가 증가할수록 크게 증가하였다. 이렇게 색차가 큰 이유는 시료를 에탄올 추출했을 때 시료 의 색성분이 충분히 추출되었기 때문으로 사료된다. 효소 반응이 일어나지 않은 $0 \mathrm{~min}$ 과 효소반응 $30 \mathrm{~min}$ 후 L값 차이 $(\Delta \mathrm{L})$ 를 보면 FSEE 농도 $2.5 \mathrm{mg} / \mathrm{mL}$ 와 $10 \mathrm{mg} / \mathrm{mL}$ 를 처리한 감자 $\mathrm{PPO}$ 의 $\Delta \mathrm{L}$ 은 각각 약 5.9 와 0.79 로 $\mathrm{FSEE}$ 의 농도가 높을수록 $\mathrm{L}$ 값의 변화는 감소하는 것으로 보아 회 향이 갈변 억제 효능이 있음을 판단할 수 있었다. 그러나 $30 \mathrm{~min}$ 에서 $\mathrm{FSEE}$ 의 농도가 높을수록 L값이 감소하는 결과 가 나타났는데 이는 FSEE의 명도와 황색도가 원인이라 사료된다. 따라서 더욱 정확한 갈변도를 판단하기 위해 $\Delta \mathrm{E}$ 값을 제시하였다. $\Delta \mathrm{E}$ 값은 $\mathrm{L}, \mathrm{a}, \mathrm{b}$ 값의 변화를 모두

Table 1. The effect of the fennel seed ethanol extracts on the changes of Hunter's values in potato extract

\begin{tabular}{|c|c|c|c|c|c|c|c|}
\hline \multirow{3}{*}{$\begin{array}{l}\text { Concentration } \\
\qquad(\mathrm{mg} / \mathrm{mL})\end{array}$} & \multicolumn{2}{|c|}{ L-value $^{1)}$} & \multicolumn{2}{|c|}{ a-value } & \multicolumn{2}{|c|}{ b-value } & \multirow{3}{*}{$\Delta \mathrm{E}$} \\
\hline & \multicolumn{6}{|c|}{ Incubation time (min) } & \\
\hline & 0 & 30 & 0 & 30 & 0 & 30 & \\
\hline 0 & $55.49 \pm 1.30^{2) \mathrm{a} 3)}$ & $49.58 \pm 0.25^{\mathrm{bc}}$ & $2.20 \pm 0.11^{\mathrm{k}}$ & $7.25 \pm 0.41^{\mathrm{h}}$ & $-0.64 \pm 0.11^{1}$ & $10.79 \pm 0.24^{f}$ & $13.82 \pm 1.10^{\mathrm{e}}$ \\
\hline 2.5 & $52.24 \pm 0.16^{\mathrm{b}}$ & $48.22 \pm 0.78^{\mathrm{d}}$ & $2.10 \pm 0.28^{\mathrm{k}}$ & $5.43 \pm 0.57^{\mathrm{i}}$ & $2.43 \pm 0.26^{\mathrm{k}}$ & $8.74 \pm 0.86^{\mathrm{g}}$ & $8.19 \pm 0.91^{\mathrm{gh}}$ \\
\hline 5 & $50.99 \pm 0.04^{\mathrm{b}}$ & $48.20 \pm 0.07^{\mathrm{d}}$ & $2.19 \pm 0.07^{\mathrm{k}}$ & $4.07 \pm 0.19^{\mathrm{ij}}$ & $5.30 \pm 0.05^{\mathrm{i}}$ & $7.64 \pm 2.27^{\mathrm{gh}}$ & $4.09 \pm 2.22^{\mathrm{ij}}$ \\
\hline 10 & $48.30 \pm 0.28^{\mathrm{cd}}$ & $47.51 \pm 0.39^{d}$ & $1.85 \pm 0.21^{\mathrm{k}}$ & $2.87 \pm 0.21^{\mathrm{jk}}$ & $9.35 \pm 0.63^{\mathrm{g}}$ & $8.65 \pm 0.82^{\mathrm{g}}$ & $1.46 \pm 0.23^{\mathrm{k}}$ \\
\hline
\end{tabular}

\footnotetext{
${ }^{1)}$ Hunter's values are L (lightness), a (redness), and b (yellowness).

${ }^{2)}$ All values represent means $\pm \mathrm{SD}(\mathrm{n}=9)$.

${ }^{3)}$ Values with different letters are significantly different at $\mathrm{p}<0.05$ based on Duncan's multiple range test $(\mathrm{p}<0.05)$.
} 
계산한 값으로 값이 클수록 색변화가 많이 일어난 것으로 판단할 수 있으며, $\Delta \mathrm{E}$ 값이 1 이상인 경우 육안으로도 색차를 확인할 수 있다(Park 등, 2012). 본 연구에서 효소반 응이 일어나기 전인 $0 \mathrm{~min}$ 과 효소반응이 일어난 $30 \mathrm{~min}$ 을 각 농도별로 비교한 $\Delta \mathrm{E}$ 값은 $\mathrm{FSEE}$ 농도 $2.5 \mathrm{mg} / \mathrm{mL}, 5$ $\mathrm{mg} / \mathrm{mL}$ 와 $10 \mathrm{mg} / \mathrm{mL}$ 에서 각각 $8.19,4.09,1.46$ 으로 $\mathrm{FSEE}$ 의 농도가 클수록 색변화가 낮았다. 특히 $10 \mathrm{mg} / \mathrm{mL}$ 의 FSEE 를 처리하였을 때의 비교한 $\Delta \mathrm{E}$ 값은 육안으로 그 변화를 감지하는 기준인 1 이상으로 $\mathrm{FSEE}$ 의 항갈변 효과를 확인 할 수 있었다. 이 결과는 Fig. 1에서 확인한 감자 PPO 활성 저해능 결과와도 일치하여 회향의 천연 항갈변제로 활용 가능성을 확인할 수 있다. 또한, 잘 알려진 갈변저해제인 ascorbic acid와 저해능을 비교하기 위해 각 실험의 the half maximal inhibitory concentration $\left(\mathrm{IC}_{50}\right)$ 을 계산하였다. FSEE 의 $\mathrm{IC}_{50}$ 는 $1.50 \pm 0.17 \mathrm{mg} / \mathrm{mL}$ 이고 ascorbic acid의 $\mathrm{IC}_{50}$ 는 $1.56 \pm 0.07 \mathrm{mg} / \mathrm{mL}$ 로 나타나 $\mathrm{FSEE}$ 의 감자 $\mathrm{PPO}$ 저해능은 ascorbic acid의 저해능과 유사한 것으로 나타났다.

감자 $\mathrm{PPO}$ 에 대해 FSEE가 어떤 저해 양상을 보이는지 평가하기 위해 Lineweaver-Burk plot를 시행한 결과는 Fig. 2와 같다. 기질 catechol에 대한 대조군과 농도 $10 \mathrm{mg} / \mathrm{mL}$ 의 $\mathrm{FSEE}$ 직선은 Y축에서 교차하지 않으며, $K_{m}$ 값은 $7 \mathrm{mM}$ 이 고 대조군의 $V_{\max }$ 값은 $1.17 \mathrm{mM} / \mathrm{min}$, 회향 에탄올 추출물의 $\mathrm{V}_{\max }$ 값은 $0.2 \mathrm{mM} / \mathrm{min}$ 으로 나타났다. 이를 통하여 감자 $\mathrm{PPO}$ 의 서로 다른 부위에 회향 에탄올 추출물과 catechol이

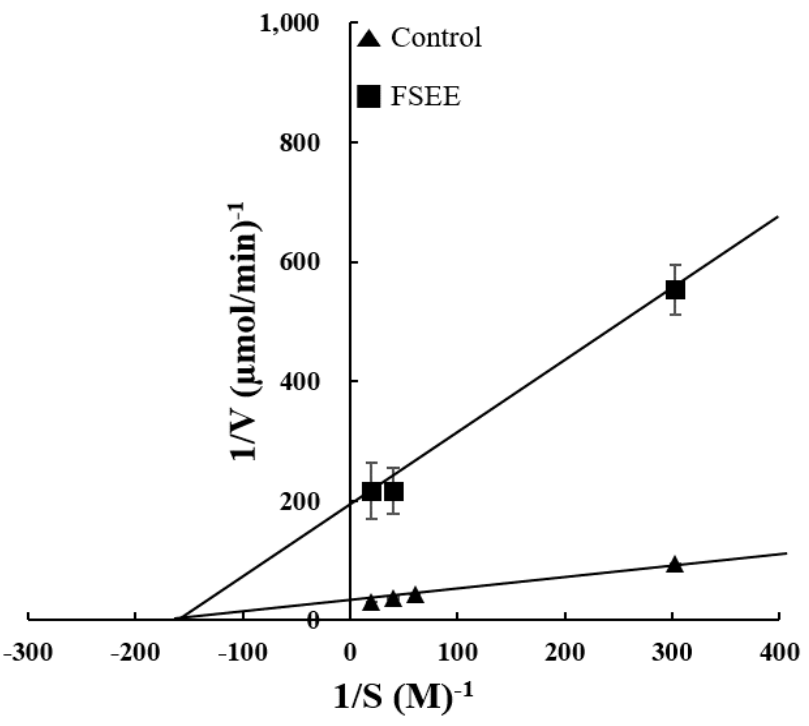

Fig. 2. Fennel seed ethanol extract (FSEE) as a noncompetitive inhibitor of potato polyphenol oxidase (PPO).

Inhibition mode of FSEE against potato PPO was analyzed by Lineweaver-Burk plot using catechol as a substrate of potato PPO with or without FSEE $(10 \mathrm{mg} / \mathrm{mL})$. Data were obtained from three independent experiments. Statistical analysis was performed using Duncans's multiple range test. (A) control, (ם) $10 \mathrm{mg} / \mathrm{mL}$ FSEE.
각각 따로 결합하고 구조적 유사성도 없는 비경쟁 저해 (noncompetitive inhibition)를 하는 것으로 나타났다. 또한, 감자 PPO 활성 저해에 관련된 다른 연구에서 보면 Kim 등(2005)은 onion 추출물이 비경쟁 저해제로 작용한다고 보고하였고, Sukhontha 등(2016)은 쌀겨 추출물이 혼합 저 해제(mixed-type inhibitor)로 작용한다고 보고하였다.

\section{$\mathrm{FSEE}$ 의 라디칼 소거능 평가}

$\mathrm{DPPH}$ 는 짙은 자주색을 나타내며 질소 중심의 안정한 free radical로 항산화 활성이 있는 물질로부터 전자나 수소 를 제공받아 DPPH-H로 환원되면서 노란색으로 탈색되므 로 DPPH radical 소거능은 흡광도가 감소할수록 높은 항산 화능을 의미한다(Brand-Williams 등, 1995). FSEE의 DPPH radical 소거능을 조사한 결과는 Fig. 3 과 같다. FSEE 시료 의 농도가 높을수록 라디칼 소거능이 높아져 농도 0.25 $\mathrm{mg} / \mathrm{mL}$ 에서 $0.831 \mathrm{mgAAE} / \mathrm{mL}$, 농도 $0.5 \mathrm{mg} / \mathrm{mL}$ 에서 1.423 $\mathrm{mgAAE} / \mathrm{mL}$, 농도 $1 \mathrm{mg} / \mathrm{mL}$ 에서 $2.342 \mathrm{mgAAE} / \mathrm{mL}, 2$ $\mathrm{mg} / \mathrm{mL}$ 에서 $3.129 \mathrm{mgAAE} / \mathrm{mL}$ 로 측정되었다. Anwar 등 (2009)은 $80 \%$ 에탄올에서 회향씨앗 추출물 DPPH radical 소거능의 $\mathrm{IC}_{50}$ 를 $23.61 \mu \mathrm{g} / \mathrm{mL}$ 로 보고했는데, 본 연구에서 는 $9.57 \mathrm{mg} / \mathrm{mL}$ 로 측정되었다. 이는 추출방법과 회향 원산 지의 차이에 따른 것으로 Anwar 등(2009)은 회향씨앗 분말 을 상온, 8 시간 조건에서 3 회 반복 추출하여 추출수율이 더 높은 것이 원인이라 사료된다.

$\mathrm{ABTS}$ 는 potassium persulfate와 반응하여 ABTS cation radical이 생성되면 청록색을 띠게 되는데 이때 항산화 물 질과 반응하여 ABTS cation radical이 소거되면서 청록색 이 탈색되는(Re 등, 1999) 원리로 높은 탈색율을 보일수록

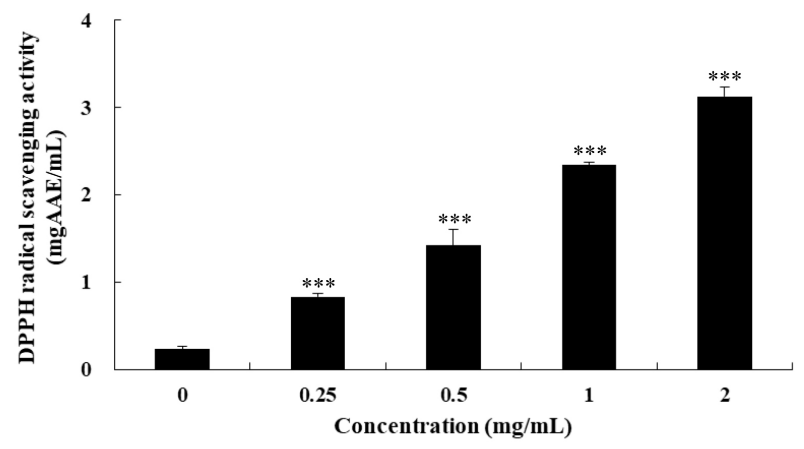

Fig. 3. DPPH radical scavenging activity of fennel seed ethanol extract (FSEE).

DPPH radical scavenging activity of various concentrations $(0 \mathrm{mg} / \mathrm{mL}$ $0.25 \mathrm{mg} / \mathrm{mL}, 0.5 \mathrm{mg} / \mathrm{mL}, 1 \mathrm{mg} / \mathrm{mL}, 2 \mathrm{mg} / \mathrm{mL}$ ) of FSEE was determined at $510 \mathrm{~nm}$. DPPH radical scavenging activity is expressed in milligrams ascorbic acid equivalents per milliliter of ethanol extracts $(\mathrm{mgAAE} / \mathrm{mL})$. Experiments were performed in triplicate and repeated three times with similar results. Bar are represented as means \pm SD $(n=9)$. Statistical analysis was performed using Dunnett's test $\left({ }^{* *} \mathrm{p}<0.01\right.$ and ${ }^{* * *} \mathrm{p}<0.001$ vs control). 
라디칼 소거능이 높다. ABTS radical 소거능을 조사한 결 과는 Fig. 4와 같다. 시료의 농도가 높을수록 라디칼 소거능 이 높아져 농도 $0.25 \mathrm{mg} / \mathrm{mL}$ 에서 $1.388 \mu \mathrm{MTE} / \mathrm{mL}$, 농도 $0.5 \mathrm{mg} / \mathrm{mL}$ 에서 $1.840 \mu \mathrm{MTE} / \mathrm{mL}$, 농도 $1 \mathrm{mg} / \mathrm{mL}$ 에서 2.785 $\mu \mathrm{MTE} / \mathrm{mL}$ 로 나타나 농도에 따른 유의적 차이를 보였으며, 가장 높은 농도인 $2 \mathrm{mg} / \mathrm{mL}$ 의 $\mathrm{FSEE}$ 에서는 $4.14 \mu \mathrm{MTE} / \mathrm{mL}$ 로 나타났다.

\section{FSEE의 환원력 측정}

FRAP assay는 ferric ion이 ferrous로 전환되는 과정을 분석함으로써 항산화력을 측정하는 방법으로 낮은 $\mathrm{pH}$ 에 서 시료의 항산화 성분에 의해 ferric tripyridyltriazine ( $\left.\mathrm{Fe}^{3+}-\mathrm{TPTZ}\right)$ 복합체가 ferrous tripyridyltriazine( $\left.\mathrm{Fe}^{2+}-\mathrm{TPTZ}\right)$ 으로 환원되는 원리를 이용한 것이다(Benzie과 Strain, 1996). FSEE의 환원력을 측정한 결과는 Fig. 5 와 같다. 시료 의 농도가 증가할수록 환원력이 높아져 농도 $0.25 \mathrm{mg} / \mathrm{mL}$, $0.5 \mathrm{mg} / \mathrm{mL}, 1 \mathrm{mg} / \mathrm{mL}$ 에서 $1.842 \mu \mathrm{MFe}^{2+} / \mathrm{mL}, 2.820 \mu \mathrm{MFe}^{2+} / \mathrm{mL}$, $4.540 \mu \mathrm{MFe}^{2+} / \mathrm{mL}$ 로 각각 나타나, 농도에 따른 유의적 차이 를 보였다. 이는 Goswami와 Chatterjee(2014)가 보고한 농 도 $1 \mathrm{mg} / \mathrm{mL}$ 회향 메탄올 추출물의 환원력인 $1,172.97$ $\mu \mathrm{MFe}^{2+} / \mathrm{L}$ 보다 높게 나타났고, 이는 추출 용매 차이에서 기인한 것으로 여겨진다.

\section{FSEE의 총 폴리페놀 및 플라보노이드 함량 분석}

$\mathrm{FSEE}$ 의 총 폴리페놀 함량을 측정한 결과는 $\mathrm{FSEE}$ 농도 가 높을수록 총 폴리페놀 함량이 높아졌다(Fig. 6). 농도 $0.25 \mathrm{mg} / \mathrm{mL}$ 에서 $0.269 \mathrm{mgGAE} / \mathrm{mL}$, 농도 $0.5 \mathrm{mg} / \mathrm{mL}$ 에서 $0.525 \mathrm{mgGAE} / \mathrm{mL}$, 농도 $1 \mathrm{mg} / \mathrm{mL}$ 에서 $0.934 \mathrm{mgGAE} / \mathrm{mL}$ 로

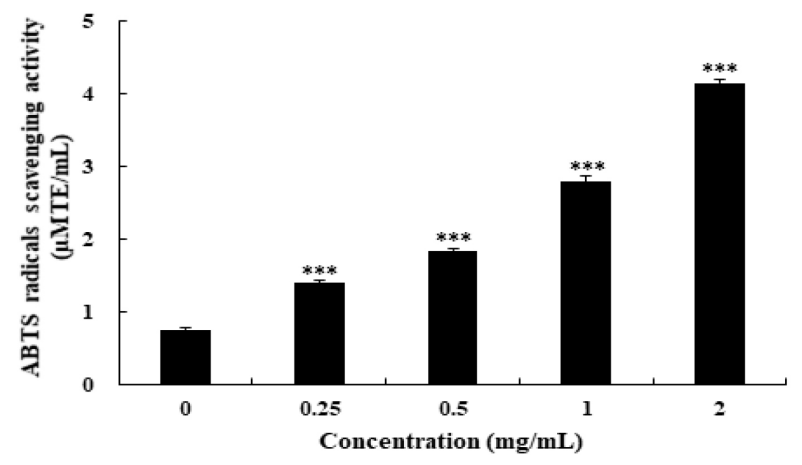

Fig. 4. ABTS radical scavenging activity of fennel seed ethanol extract (FSEE).

ABTS radical scavenging activity of FSEE was measured at $734 \mathrm{~nm}$. ABTS radical scavenging activity is expressed in micromole trolox equivalents per milliliter of ethanol extracts $(\mu \mathrm{MTE} / \mathrm{mL})$. Experiments were performed in triplicate and repeated three times with similar results. Bar are represented as means $\pm \mathrm{SD}(\mathrm{n}=9)$. Statistical analysis was performed using Dunnett's test $\left({ }^{* * *} \mathrm{p}<0.001\right.$ vs control).

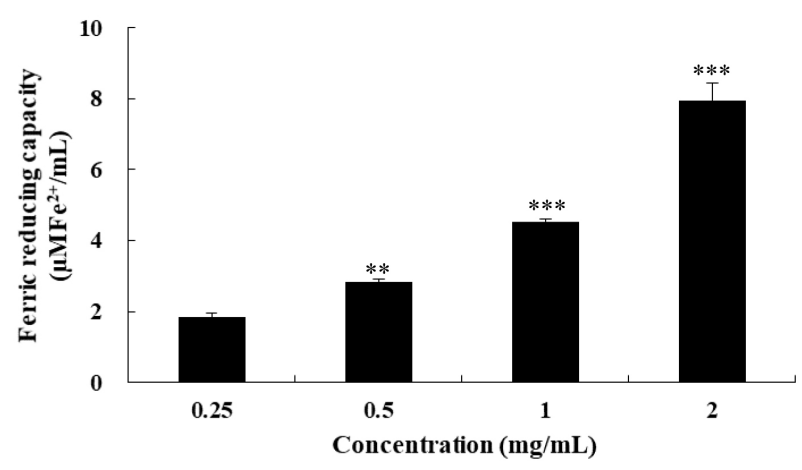

Fig. 5. Ferric reducing activity of fennel seed ethanol extract (FSEE).

FSEE at 0 to $2 \mathrm{mg} / \mathrm{mL}$ was subjected to the FRAP assay to investigate the reducing power of FSEE. Ferric reducing activity is expressed in micromole ferrous sulfate equivalents per milliliter of ethanol extracts $\left(\mu \mathrm{MFE} 2^{+} / \mathrm{mL}\right)$. Experiments were performed in triplicate and repeated three times with similar results. Bar are represented as mean $\pm \mathrm{SD}(\mathrm{n}=9)$. Statistical analysis was performed using Dunnett's test $\left({ }^{* *} \mathrm{p}<0.01\right.$ and $\mathrm{p}<0.001$ vs $0.25 \mathrm{mg} / \mathrm{mL}$ FSEE).

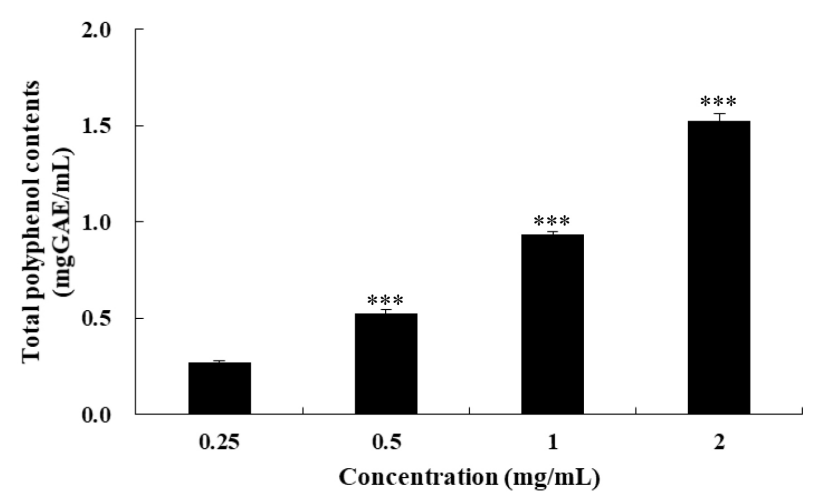

Fig. 6. Total polyphenol contents of fennel seed ethanol extract (FSEE).

Total phenolic contents were examined by the Folin-Ciocalteu method. Total polyphenol contents are expressed in milligrams gallic acid equivalents per milliliter of FSEE $(\mathrm{mgGAE} / \mathrm{mL})$. Experiments were performed in triplicate and repeated three times with similar results. Bar are represented as mean $\pm S D(n=9)$. Statistical analysis was performed using Dunnett's test $\left({ }^{* * *} \mathrm{p}<0.001\right.$ vs $0.25 \mathrm{mg} / \mathrm{mL}$ FSEE).

나타나, 시료의 농도가 2 배 증가할 때마다 총 폴리페놀 함량도 약 2 배씩 증가하는 것으로 나타났다. 이는 회향씨 앗에 강하게 결합된 총 폴리페놀이 에탄올 추출로 인해 수용성 상태가 되어 생물학적 이용가능성이 증가했기 때 문으로 사료된다(Alonso 등, 2004). 농도 $1 \mathrm{mg} / \mathrm{mL}$ 의 FSEE 의 총 폴리페놀 함량은 $934 \mathrm{mgGAE} / \mathrm{g}$ 으로 Roby 등(2013)의 연구결과보다 높게 나타났다. 이는 Faudale 등(2008)이 보 고한 용도와 원산지가 서로 다른 회향씨앗의 총 폴리페놀 함량과 총 플라보노이드 함량이 다르다는 연구결과를 근 거로 하였을 때, 원산지의 차이에서 기인한 것이라 사료된 
다. FSEE의 총 플라보노이드 함량을 측정한 결과는 Fig. 7과 같다. 총 플라보노이드 함량은 농도 $0.25 \mathrm{mg} / \mathrm{mL}$ 에서 $1.243 \mathrm{mgCE} / \mathrm{mL}$, 농도 $0.5 \mathrm{mg} / \mathrm{mL}$ 에서 $1.377 \mathrm{mgCE} / \mathrm{mL}$, 농 도 $1 \mathrm{mg} / \mathrm{mL}$ 에서 $1.621 \mathrm{mgCE} / \mathrm{mL}$ 로 나타나 농도에 따른 유의적 차이를 보였다.

페놀성 화합물은 다양한 구조로 식물계에 널리 존재하고 있으며 플라보노이드는 페놀성 화합물 중에서 자연적으로 생성되는 가장 큰 그룹 중 하나이다(Miean과 Mohamed, 2001). 이들은 phenolic hydroxyl기를 지닌 방향족 구조로 인해 높은 항산화능을 나타낸다. 따라서 Fig. 3-5에서 확 인한 FSEE의 항산화능은 FSEE에 포함된 총 폴리페놀과 총 플라보노이드 때문으로 판단된다. 따라서 이상의 결과 들을 통해 $\mathrm{FSEE}$ 는 감자 $\mathrm{PPO}$ 를 비경쟁적으로 억제하며 항갈변 효능이 있음을 확인하였을 뿐만 아니라, FSEE를 서로 다른 기전을 가진 $\mathrm{DPPH}$ 법, $\mathrm{ABTS}$ 법, FRAP법을 통해 측정한 결과 농도의존적 항산화능을 확인하였고, 이러한 항산화능은 $\mathrm{FSEE}$ 의 총 폴리페놀과 총 플라보노이드 때문 으로 여겨진다. 따라서 FSEE는 감자의 갈변을 억제하는 천연 항갈변제로 활용가능성이 있으며, 동시에 항산화 기 능성이 부여되므로 상품의 가치를 높일 수 있다고 판단된 다. 향후 FSEE를 신선편이제품 가공에 직접적으로 활용하 였을 때의 품질변화를 조사하는 추가 연구가 필요할 것으 로 판단된다.

\section{요 약}

신선편이식품 제조과정에서 세척, 박피, 절단 등의 공 정 중 과일류와 채소류의 경우 갈변으로 인하여 품질저하 가 우려되며, 이를 억제하기 위하여 공정 중 합성화합물을

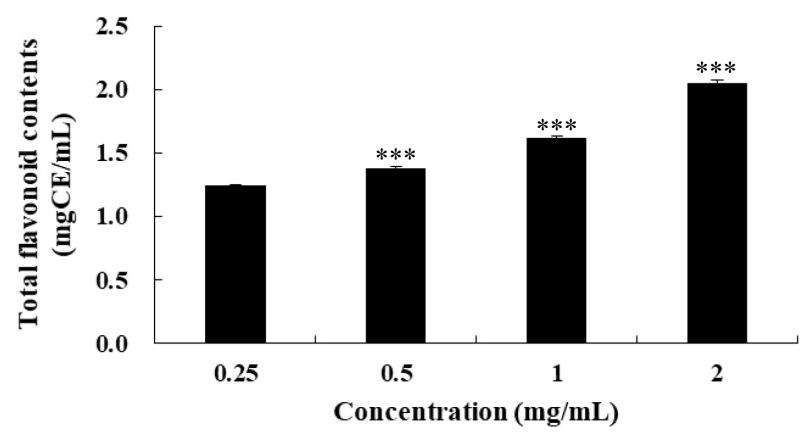

Fig. 7. Total flavonoid contents of fennel seed ethanol extract (FSEE).

Total flavonoid contents were analyzed by the aluminum chloride colorimetric method. Total flavonoid contents are expressed in milligrams catechin equivalents per milliliter of FSEE $(\mathrm{mgCE} / \mathrm{mL})$. Experiments were performed in triplicate and repeated three times with similar results. Bar are represented as mean $\pm \mathrm{SD}(\mathrm{n}=9)$. Statistical analysis was performed using Dunnett's test ( ${ }^{* * *}$ p $<0.001$ vs $0.25 \mathrm{mg} / \mathrm{mL}$ FSEE).
첨가한다. 최근 소비자들의 건강에 대한 관심이 증가하여 합성첨가물을 지양하고 건강기능성이 추가된 식품에 대 한 소비가 증가하고 있는 추세이다. 따라서 신선편이식품 의 품질과 건강기능성을 높이기 위한 새로운 천연유래 식품첨가물의 개발 필요성이 대두되고 있다. 회향씨앗은 민간에서 의학적으로 사용해온 식물로서 다양한 생리적 활성이 밝혀져 왔으나, 항갈변 효능에 대한 연구는 전무한 실정이다. 본 연구에서는 항갈변 기능을 가지며 항산화 능력을 가지는 식품첨가물로서 회향씨앗의 가능성을 감 자 polyphenol oxidase에 대한 효소활성 억제와 폴리페놀 및 플라보노이드 함량, DPPH 및 ABTS radical 소거능, FRAP assay를 통하여 조사하였다. 회향씨앗에탄올추출 물(Fennel Seed Ethanol Extract, FSEE) 농도 $10 \mathrm{mg} / \mathrm{mL}$ 감자 $\mathrm{PPO}$ 활성을 $85.47 \%$ 저해하며, $\mathrm{IC}_{50}$ 는 $1.50 \pm 0.17 \mathrm{mg} / \mathrm{mL}$ 로 항갈변 효능을 나타냈다. 갈변도를 색차계로 측정하였을 때 대조군의 $\Delta \mathrm{E}$ 값은 $13.82 \pm 1.10$ 으로 육안으로도 색의 변화를 확인할 수 있었던 것에 비해 $10 \mathrm{mg} / \mathrm{mL} \mathrm{FSEE}$ 처리 군의 $\Delta \mathrm{E}$ 는 $1.46 \pm 0.2$ 로 나타나 FSEE 처리에 의해 갈변이 억제됨을 확인하였다. $\mathrm{FSEE}$ 의 감자 $\mathrm{PPO}$ 활성 저해모드 를 Lineweaver-Burk plot으로 도출한 결과, 감자 $\mathrm{PPO}$ 에 대해 비경쟁적 저해를 하는 것으로 나타났다. $\mathrm{FSEE}$ 의 항 산화능은 DPPH radical 소거능은 ABTS radical 소거능을 비롯하여 FRAP assay를 통해 환원력을 측정하였고, 농도 의존적 항산화능을 확인하였다. 이러한 항산화능은 총 폴리페놀과 총 플라보노이드 함량과 상관적 관계를 보여 $\mathrm{FSEE}$ 의 농도가 증가할수록 총 폴리페놀 및 총 플라보노 이드 함량이 유의적으로 증가하였다. FSEE 농도 $2 \mathrm{mg} / \mathrm{mL}$ 의 총 폴리페놀과 총 플라보노이드 함량은 각각 1.52 $\mathrm{mgGAE} / \mathrm{mL}, 2.05 \mathrm{mgCE} / \mathrm{mL}$ 로 측정되었다. 이상의 결과를 토대로 $\mathrm{FSEE}$ 는 감자 $\mathrm{PPO}$ 를 비경쟁적으로 억제하면서 항산화능을 나타내는 것으로 확인할 수 있었다. 따라서 FSEE가 신선편이제품의 품질을 높이면서 항산화 기능성 을 향상시킬 수 있는 천연 첨가물로서의 가능성을 확인할 수 있었다.

\section{감사의 글}

This research was funded by Basic Science Research Program through the National Research Foundation of Korea (NRF) funded by the Ministry of Education, grant number NRF-2018R1D1A1B07043887.

\section{Conflict of interests}

The authors declare no potential conflict of interest. 


\section{ORCID}

Joo-Yeon Lee https://orcid.org/0000-0003-4319-6341 Choon Young Kim

https://orcid.org/0000-0002-5980-4578

\section{Reference}

Alonso AM, Castro R, Rodriguez MC, Guillen DA, Barroso CG. Study of the antioxidant power of brandies and vinegars derived from Sherry wines and correlation with their content in polyphenols. Food Res Int, 37, 715-721 (2004)

Anwar F, Ali M, Hussain AI, Shahid M. Antioxidant and antimicrobial activities of essential oil and extracts of fennel (Foeniculum vulgare Mill.) seeds from Pakistan. Flavour Frag J, 24, 170-176 (2009)

Benzie IFF, Strain JJ. The ferric reducing ability of plasma (FRAP) as a measure of "antioxidant power": The FRAP assay. Anal Biochem, 239, 70-76 (1996)

Biglari F, AlKarkhi AFM, Easa AM. Antioxidant activity and phenolic content of various date palm (Phoenix dactylifera) fruits from Iran. Food Chem, 107, 1636-1641 (2008)

Braaksma A, Schaap DJ, Schipper CMA. Time of harvest determines the postharvest quality of the common mushroom Agaricus bisporus. Postharvest Biol Technol, 16, 195-198 (1999)

Brand-Williams W, Cuvelier ME, Berset C. Use of a free radical method to evaluate antioxidant activity. LWTFood Sci Technol, 28, 25-30 (1995)

Chang MS, Park MJ, Jeong MC, Kim DM, Kim GH. Antioxidative activities and antibrowning effects of green tea extracts and propolis. Korean J Food Cookery Sci, 28, 319-326 (2012)

Chen JS, Wei CI, Marshall MR. Inhibition mechanism of kojic acid on polyphenol oxidase. J Agric Food Chem, 39, 1897-1901 (1991)

Cho HJ, Yoo DC, Cho HN, Fan LA, Kim HJ, Khang KW, Jeong HS, Yang SA, Lee IS, Jhee KH. Analysis of phytochemicals in popular medicinal herbs by HPLC and GC-MS. Korean J Food Sci Technol, 40, 277-282 (2008)

Faudale M, Viladomat F, Bastida J, Poli F, Codina C. Antioxidant activity and phenolic composition of wild, edible, and medicinal fennel from different Mediterranean countries. J Agric Food Chem, 56, 1912-1920 (2008)
Goswami N, Chatterjee S. Assessment of free radical scavenging potential and oxidative DNA damage preventive activity of Trachyspermum ammi L. (carom) and Foeniculum vulgare Mill. (fennel) seed extracts. Bio Med Res Int, 2014, 582767 (2014)

Kim MJ, Kim CY, Park I. Prevention of enzymatic browning of pear by onion extract. Food Chem, 89, 181-184 (2005)

Kim YJ, Uyama H. Tyrosinase inhibitors from natural and synthetic sources: Structure, inhibition mechanism and perspective for the future. Cell Mol Life Sci, 62, 1707-1723 (2005)

Laurila E, Kervinen R, Ahvenainen R. The inhibition of enzymatic browning in minimally processed vegetables and fruits. Postharvest News and Information, 9, 53-66 (1998)

Lee BG, Seo JD, Rhee JK, Kim CY. Heated apple juice supplemented with onion has greatly improved nutritional quality and browning index. Food Chem, 201, 315-319 (2016)

Lee YN, Jeong $\mathrm{CH}$, Shim $\mathrm{KH}$. Isolation of antioxidant and antibrowning substance from Chionanthus retusa leaves. J Korea Soc Food Sci Nutr, 33, 1419-1425 (2004)

Lim JH, Choi JH, Hong SI, MC J. Mild heat treatments for quality improvement of fresh-cut potatoes. Korean J Food Preserv, 12, 552-557 (2005)

Martinez MV, Whitaker JR. The biochemistry and control of enzymatic browning. Trends Food Sci Tech, 6, 195-200 (1995)

Miean KH, Mohamed S. Flavonoid (myricetin, quercetin, kaempferol, luteolin, and apigenin) content of edible tropical plants. J Agric Food Chem, 49, 3106-3112 (2001)

Oktay M, Gulcin I, Kufrevioglu OI. Determination of in vitro antioxidant activity of fennel (Foeniculum vulgare) seed extracts. Food Sci Tech, 36, 263-271 (2003)

Oszmianski J, Lee CY. Inhibition of polyphenol oxidase activity and browning by honey. J Agric Food Chem, 38, 1892-1895 (1990)

Park YJ, Koo KM, Kim GY, Oh SK, Seo HJ, Hiroyuki M. A study on the performance evaluation of anti-corrosive material's surface quality changes by the ozone. JAIK, 28, 83-90 (2012)

Ragaert P, Verbeke W, Devlieghere F, Debevere J. Consumer perception and choice of minimally processed vegetables and packaged fruits. Food Qual Prefer, 15, 259-270 (2004)

Rather MA, Dar BA, Sofi SN, Bhat BA, Qurishi MA. Foeniculum vulgare: A comprehensive review of its 
traditional use, phytochemistry, pharmacology, and safety. Arabian J Chem, 9, 1574-1583 (2016)

Re R, Pellegrini N, Proteggente A, Pannala A, Yang M, Rice-Evans C. Antioxidant activity applying an improved ABTS radical cation decolorization assay. Free Radic Biol Med, 26, 1231-1237 (1999)

Roby MHH, Sarhan MA, Selim KAH, Khalel KI. Antioxidant and antimicrobial activities of essential oil and extracts of fennel (Foeniculum vulgare L.) and chamomile (Matricaria chamomilla L.). Ind Crops Prod, 44, 437-445 (2013)
Singleton VL, Orthofer R, Lamuela-Raventós RM. Analysis of total phenols and other oxidation substrates and antioxidants by means of Folin-Ciocalteu reagent. Methods Enzymol, 299, 152-178 (1999)

Son SM, Moon KD, Lee CY. Rhubarb juice as a natural antibrowning agent. Korean J Food Sci, 65, 1288-1289 (2000)

Sukhonthara S, Kaewka K, Theerakulkait C. Inhibitory effect of rice bran extracts and its phenolic compounds on polyphenol oxidase activity and browning in potato and apple puree. Food Chem, 190, $922-927$ (2016) 